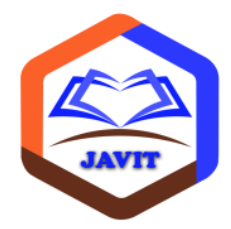

JURNAL VOKASI INFORMATIKA

(JAVIT)

Terbit online pada laman web jurnal: http://javit.ppj.unp.ac.id

DOI: https://doi.org/10.24036/javit.v2i1

ISSN: $2775-6807$

Vol. 1 No. 1 (2021) 23 - 27

\title{
Penggunaan E-Modul Dengan Sistem Project Based Learning
}

\author{
1,* Putri Nurhalimah Erdi, ${ }^{2}$ Tivsi Rizqi Padwa \\ ${ }^{1,2}$ Pendidikan Teknologi dan Kejuruan, Fakultas Teknik, Universitas Negeri Padang \\ *Coressponding author e-mail: putri.nurhalimah07@gmail.com
}

\begin{abstract}
Abstrak
Pendidikan adalah sebuah peranan penting dikehidupan manusia. Pendidikan berkaitan dengan proses belajar dan mengajar. Tujuan pembelajaran yaitu diharapkan kemampuan dari peserta didik seimbang. Belajar juga adalah proses mental yang mengakibatkan sebuah perubahan yang terjadi pada diri seseorang. Proses pembelajaran akan berjalan dengan baik jika didukung dengan tersedianya sumber belajar mengajar yang memadai, media yang menarik, dan sistem pembelajaran yang tepat. Media pembelajaran saat ini beraneka ragam dan berkembang sesuai perkembangan teknologi. Salah satu media pembelajaran yang mengikuti perkembangan teknologi saat ini adalah yaitu media pembelajaran E-modul dengan menggunakan sistem berbasis elektronik. E-modul memiliki tujuan dapat mempermudah peserta didik dalam mempelajari setiap materi pembelajaran serta peningkatan hasil belajar disetiap mata pelajaran. Sejauh ini sudah banyak yang mengembangkan dengan e-modul dengan beberapa model sistem pembelajaran. Salah satunya dengan sistem pembelajaran project based learning yang juga merupakan pembelajaran yang inovatif, kreatif, dengan berpusat pada siswa yang menempatkan guru sebagai motivator dan fasilitator. Pembelajaran dengan menggunakan emodul ternyata bahkan lebih efektif dan mudah dipahami oleh perserta didik
\end{abstract}

Kata kunci : Pendidikan, Proses Pembelajaran, E-Modul, Pembelajaran Berbasis Proyek, Media Pembelajaran.

(C) Lisensi: Creative Commons Attribution 4.0 International (CC BY 4.0) 


\section{Pendahuluan}

Pendidikan adalah sebuah peranan penting dikehidupan manusia, dengan menikmati pendidikan manusia bisa meningkatkan kehidupan taraf hidupnya. Pendidikan berkaitan dengan proses belajar dan mengajar, dimana proses belajar berpusat pada siswa dan proses mengajar berpusat pada pendidik. Tujuan dari pendidikan pada dasarnya adalah rumusan yang sangat komprehensif tentang apa yang seharusnya dicapai, yang memuat dengan pernyataan mengenai berbagai kemampuan yang diharapkan dapat dimiliki oleh peserta didik seimbang dengan sistem nilai dan falsafah yang dianutnya.

Belajar juga adalah proses mental yang mengakibatkan sebuah perubahan yang terjadi didiri seseorang yang mengakibatkan munculnya sebuah perubahan sikap, perilaku, ataupun penambahan dalam sebuah pengetahuan. Dalam perkembangan di era 4.0 ini memberikan pengaruh yang sangat besar terhadap kualitas dalam sebuah pendidikan terutama di Indonesia. Dimana perkembangan di era ini menuntut untuk mampu berpikir kreatif, inovatif, dan siap bersaing untuk meningkatkan kesejahteraaan bangsa dengan perubahan era di zaman perubahan yang sedang terjadi. Dengan salah satu caranya yaitu menggunakan pendidikan dengan sistem teknologi dengan media pembelajaran yang mampu membuat peserta didik dapat mengembangkan potensi dirinya dengan baik dan secara aktif.

Proses pembelajaran akan berjalan dengan baik jika didukung dengan tersedianya sumber belajar mengajar yang memadai, media yang menarik, dan sistem pembelajaran yang tepat. Salah satu upaya dalam meningatkan proses pembelajaran dengan cara meningkatkan penggunaan media yang secara efektif mempertinggi kualitas pada akhirnya meningkatkan kualitas hasil belajar menjadi lebih baik. Salah satu upayanya yaitu penggunaan bahan ajar yang tepat dan cermat sesuai kebutuhan era di zaman 4.0 yang sampai saat sekarang ini masih mampu bertahan dan bersaing dengan bahan ajar lainnya, yitu dengan menggunakan modul.

Modul merupakan sebuah alat yang menjadi salah satu sarana pendidikan dalam pembelajaran yang didalamnya terdapat berupa materi, metode, dan evaluasi yang dibuat secara sistematis, tersusun, dan terstruktur sebagai upaya untuk mencapai tujuan kompetensi yang diharapkan. Modul dirancang secara khusus dan sangat jelas sesuai dengan kecepatan pemahaman masing-masing peserta didik sehingga dapat mendorong untuk melakukan sistem belajar mengajar sesuai dengan taraf kemampuan masing-masing peserta didik.

Seiring pada perkembangan teknologi, terjadinya perpaduan antara media cetak dengan media komputer pada sistem belajar mengajar. Salah satunya termasuk dalam hal ini dengan modul yang ditransformasikannya penyajian dalam bentuk media elektronik yang mampu dan dapat diakses dimana saja dengan efektifitas yang baik sehingga melahirkan dengan menggunakan istilah modul elektronik atau biasa disebut dengan e-modul. Emodul merupakan sebuah media pembelajaran dengan sistem berbasis elektronik. Didalamnya terdapat dengan materi dalam bentuk teks, gambar dalam bentuk animasi, metode, evaluasi, grafik, dan video.

E-modul bisa diakses dan dipelajari melalui media elektronik dimana dan kapan saja. Dengan menggunakan e-modul peserta didik mampu akan lebih cepat dan mudah dalam memahami dan memperlajari materi pembelajaran dengan pengembangan proses pembelajaran yang tidak hanya dengan membaca gaya teks book tetapi juga dengan menggunakan beberapa metode lainnnya. Emodul dengan bentuk penyajian bahan ajar mengajar untuk belajar mandiri disusun dengan sangat sistematis, terarah, dan terstruktur kedalam unit pembelajaran terkecil agar mencapai tujuan pembelajaran sesuai yang diharapkan dengan disajikan dalam bentuk elektronik yang mampu diakses kapan saja.

Belajar menggunakan e-modul, maka dituntut untuk untuk bisa belajar secara mandiri, kreatif, inovatif, serta bermotivasi tinggi dalam mengikuti setiap pembelajaran agar belajar mengajar menggukan e-modul berjalan dengan baik. Dengan e-modul diharapkan mempu digunakan menjadi sumber belajar mengajar bagi peserta didik dan dapat meningkatkan pemahaman dalam konsep pembelajaran. Bahan ajar yang menggunakan emodul akan mengarahkan peserta didik untuk melaksanakan pembelajaran yang lebih mandiri dan menuntun untuk lebih membantu peserta didik yang dalam proses belajar mengajar mengalami kelemahan dalam mencerna dan memahami sebuah permbelajaran, karena e-modul dapat diartikan juga dengan sebuah alat bantu dalam proses belajar mengajar yang dikemas dalam bentuk elektronik atau visualisasi. Yang dalam hal ini tentu saja harus ada beberapa komponen yang akan sangat membantu pemnggunaan e-modul seperti alat elektronik perangkat komputer, laptop, ataupun handphone.

Bahan belajar mengajar yang baik saja tidak cukup untuk menciptakan sebuah pembelajaran yang bermakna, selain bahan pembelajaran harus seimbang dengan sistem dan metode pembelajaran agar hasil yang sesuai dengan harapan. Model pembelajaran memiliki banyak sistem, yakninya sistem pembelajaran Problem Based Introduction (PBI), Problem Based Learning (PBL), Project Based Learning (PjBL) dan masih banyak sistem lainnya. Sistem belajar yang mampu menjadi 
fasilitas utuk peserta didik dalam pemecahan masalah sesuai zamannya adalah dengan menggunakan sistem pembelajaran project based learning atau yang biasa dikenal dengan sistem PjBL.

Project Based Learning (PjBL) merupakan sistem pembelajaran dengan sistem yang memberikan kesempatan dan ruang kepada peserta didik untuk mengolah dan mengelola pembelajaran di ruang kelas dengan melibatkan banyak orang atau kerja proyek. Project based learning juga merupakan pembelajaran yang inovatif, kreatif, dengan berpusat pada siswa yang menempatkan guru sebagai motivator dan fasilitator dimana siswa diberikan peluang untuk mengembangkan kemampuan diri secara lebih otonom dengan menginstruksikan belajarnya.

Tujuannya adalah dapat menyelesaikan tugas yang dihadapi peserta didik secara lebih mandiri dengan bantuan e-modul dengan model karakteristik sistem pembelajaran project based learning yang dapat memanfaatkan media elektronik kompter, laptop, dan handphone dengan mengembangkan kemampuan pribadi siswa. Dalam hal ini, maka dilakukan review untuk beberapa artikel dalam mengumpulkan data mengenai aktivitas penggunaan e-modul dengan sistem project based learning.

\section{Tinjauan Pustaka}

Dalam Kamus Besar Bahasa Indonesia, belajar dapat diartikan sebagai usaha memperoleh kepandaian atau ilmu. Dapat diartikan bahwa belajar adalah suatu kegiatan untuk mencapai suatu kemampuan atau keterampilan, kepandaian atau ilmu yang dilakukan terus menerus sehingga seseorang dapat bersikap sesuai aturan yang ada Teori belajar merupakan suatu upaya untuk menggambarkan dan menjelaskan bagaimana manusia dan hewan dalam proses belajarnya, sehingga dapat membantu kita dalam memahami proses kompleks dari pembelajaran.

Menurut Azhar Arsyad [8] belajar merupakan suatu proses yang kompleks yang terjadi pada diri setiap orang sepanjang hidupnya. Proses belajar itu terjadi karena adanya interaksi antara sesorang dengan lingkungannya. Oleh karena itu, belajar dapat terjadi kapan saja dan dimana saja. Salah satu pertanda bahwa sesorang itu telah belajar adalah adanya perubahan tingkah laku pada diri orang itu yang mungkin disebabkan oleh terjadinya perubahan pada tingkat pengetahuan, ketrampilan, atau sikapnya.

Berdasarkan ketentuan Peraturan Pemerintah Nomor 19 Tahun 2005 yang kemudian diikuti dengan Peraturan Menteri Pendidikan Nasional Nomor 41 Tahun 2007, standar proses pembelajaran harus meliputi perencanaan proses pembelajaran, pelaksanaan proses pembelajaran, penilaian hasil pembelajaran, dan pengawasan proses pembelajaran untuk terlaksananya proses pembelajaran yang efektif dan efisien.

Dalam proses pembelajaran salah satu hal yang dibutuhkan adalah media pembelajaran. Media Pembelajaran menurut Asyar [9] adalah hal-hal yang dapat menjelaskan, menyampaikan atau menyalurkan pesan dari satu sumber secara terstruktur, sehingga terjadi lingkungan belajar yang kondusif dimana penerimanya dapat melakukan proses belajar secara efisien dan efektif.

Project-Based Learning berisi enam fase utama yang dimulai dengan orientasi masalah yang disampaikan guru untuk mengarahkan siswa tentang situasi masalah, membentuk kelompok belajar siswa, melakukan investigasi atau penyelidikan individual maupun kelompok, merencanakan dan menyajikan laporan, presentasi dan analisis laporan, dan evaluasi. Jika ruang lingkup masalah yang diberikan sempit, maka enam fase dapat diselesaikan dalam satu periode di kelas, namun jika ruang lingkup masalah luas dan kompleks, mungkin memerlukan waktu yang lebih banyak [6].

Project Based Learning yang merupakan salah satu dari 4 model pembelajaran utama yang pelaksanaanya sesuai dengan Kurikulum 2013 [7]. Penilaian kinerja pada PjBL dapat dilakukan secara individual oleh peserta didik yaitu dengan memperhitungkan kualitas produk yang dihasilkan, kedalaman pemahaman konten yang ditunjukkan, serta kontribusi yang diberikan pada saat proses realisasi proyek yang sedang berlangsung.

Beberapa syarat yang harus dipenuhi sebelum melakukan proses pembelajran Project Based Learning adalah (a) pendidik harus memiliki keterampilan dalam mengidentifikasi kompetensi dasar yang lebih menekankan pada aspek keterampilan atau pengetahuan pada tingkat penerapan, analisis, sintesis, dan evaluasi; (b) pendidik mampu memilih materi atau topik-topik yang akan dijadikan tema proyek sehingga menjadi menarik; (c) pendidik harus terampil menumbuhkan motivasi peserta didik dalam mengerjakan proyek; (d) adanya fasilitas dan sumber belajar yang cukup; d. pendidik harus melihat kesesuaian waktu proyek dengan kalender akademik sehingga kegiatan proyek memungkinkan akan dilakukan.

Terdapat perbedaan hasil belajar antara siswa yang diajar dengan metode PjBL dengan yang diajar dengan metode demonstrasi ditinjau dari motivasi tinggi dan rendah. Hasil dari penelitian ini menunjukkan bahwa penggunaan metode $\mathrm{PjBL}$ memberikan hasil belajar yang lebih baik daripada metode demonstrasi, ditinjau dari siswa yang memiliki motivasi tinggi ataupun rendah. Dalam upaya untuk mengimplementasikan pembelajaran melalui model PjBL dibutuhkan bahan ajar yang sesuai dengan kurikulum yang berlaku. Bahan ajar 
yang dapat digunakan berdasarkan kurikulum saat ini adalah menggunakan e-modul.

Perkembangan teknologi e-book mendorong terjadinya perpaduan antara teknologi cetak dengan teknologi komputer dalam kegiatan pembelajaran. berbagai media pembelajaran cetak, salah satunya modul dapat ditransformasikan penyajiannya ke dalam bentuk elektronik, sehingga melahirkan istilah modul elektronik atau yang dikenal dengan istilah e-modul. Istilah modul elektronik merupakan penggabungan istilah modul dalam bentuk bahan ajar elektronik (e-book). Sebenarnya tidak ada perbedaan prinsip pengembangan antara modul konvensional (cetak) dengan modul elektronik. Perbedaan hanya terdapat pada format penyajian secara fisik saja, sedangkan komponen penyusun modul tersebut tidak memiliki perbedaan. Modul elektronik mengadaptasi komponen-komponen yang terdapat dalam modul cetak pada umumnya. Perbedaan hanya pada penyajian fisik modul elektronik yang membutuhkan perangkat komputer untuk menggunakannya dan memerlukan aplikasi tambahan untuk menjalankan modul elektronik tersebut yang dikenal dengan e-book reader. Beberapa contoh aplikasi $e$-book reader antara lain Nook, Kobo, Kindle, Magic Scroll. Sebagian besar ponsel keluaran terbaru juga sudah mendukung penggunaan aplikasi e-book, sehingga bisa memudahkan pengguna dalam mempelajari suatu materi pelajaran [8].

Modul elektronik (e-modul) merupakan pengembangan modul cetak dalam bentuk digital yang banyak mengadaptasi dari modul cetak. Emodul merupakan transformasi dari modul cetak yang disajikan dalam bentuk elektronik. kelebihan e-modul dibandingkan dengan modul cetak adalah sifatnya yang interaktif memudahkan dalam navigasi, memungkinkan menampilkan/memuat gambar, audio, video, dan animasi, tahan lama, lebih praktis dibawa-bawa serta dilengkapi tes/kuis formatif yang memungkinkan umpan balik otomatis dengan segera [6].

Dalam mencari materi pembelajaran jika menggunakan internet, informasi yang diterima siswa akan terlalu banyak dan dapat menjadi kacau dan sulit dimengerti. E-Modul dapat dijadikan wadah bagi siswa untuk menyaring informasi yang didapatkan dan juga menjadi acuan bagi siswa serta dapat dijadikan wadah untuk mencari informasi materi pembelajaran. Keunggulan lain e-modul dalam proses pembelajaran terletak pada tahapan pembelajaran berdasarkan masalah, yaitu orientasi peserta didik kepada masalah, mengorganisasi peserta didik untuk belajar, membimbing penyelidikan individual maupun kelompok, mengembangkan dan menyajikan hasil karya, serta menganalisis dan mengevaluasi proses pemecahan masalah. Pengembangan e-modul dapat dipadukan dengan model pembelajaran yang dipandang mampu meningkatkan hasil belajar peserta didik.

\section{Metode Penelitian}

Pencarian data ini dilakukan dengan cara menggunakan Google Schoolar dan Sinta 2, dengan menggunakan kata kunci "E-Modul dengan Project Based Learning" dengan menggunakan jumlah penelitian yang di review pada kategori Google Schoolar dan Sinta 2 berjumlah enam artikel dan dijabarkan dengan menggunakan metode analisis deskriptif. Sumber atau referensi yang telah diperoleh ini telah dimetakan dan ditetapkan dengan menggunakan kriteria inklusi.

\section{Hasil dan Pembahasan}

Project Based Learning (PjBL) merupakan model pembelajaran yang sesuai dengan kurikulum 2013. Model pembelajaran ini merupakan pembelajaran yang terpusat pada siswa. Project based learning (PjBL) dalam implementasinya ada beberapa kegiatan yang harus dilakukan oleh peserta didik. Peserta didik tidak hanya memahami konten, tetapi juga menumbuhkan keterampilan pada peserta didik bagaimanan berperan di masyarakat. Keterampilan yang ditumbukan dalam PjBl diantaranya keterampilan komunikasi dan presentasi, keterampilan manajemen organisasi dan waktu, keterampilan penelitian dan penyelidikan, keterampilan penilaian diri dan refleksi, partisipasi kelompok dan kepemimpinan, dan pemikiran kritis.

Pengembangan modul elektronik dengan modifikasi penambahan model pembelajaran project based learning kedalam modul tersebut, dapat mengatasi masalah kebosanan siswa dalam proses pembelajaran. Oleh karena itu modul menggunakan model Project based learning (PjBL) menjadi salah satu solusi dalam mengembangkan media pembelajaran di Sekolah Menengah Kejuruan.

Dalam penggunaannya e-modul telah diuji oleh beberapa ahli, yaitu uji ahli isi pembelajaran, lalu uji ahli design dan selanjutkan uji ahli media pembelajaran. Setelah e-modul layak dan sesuai, tahap ujicoba dapat dilakukan. dalam tahap ujicoba diberikan kepada guru dan kepada siswa. Dalam beberapa penelitian dilakukan pembagian kelas, yaitu kelas ujicoba dan kelas kontrol. Di dalam sebuah penelitian dinyatakan bahwa e-modul yang dipakai telah efektif dan sesuai dalam pembelajaran. Dengan menggunakan e-modul bahkan dapat meningkatkan pemahaman peserta didik dibandingkan menggunakan media jobsheet. Pembelajaran bahkan berjalan lebih efektif dan mudah dipahami. E-modul sendiri bertujuan untuk mempermudah peserta didik dalam mempelajari materi serta dapat meningkatkan hasil belajar [4][5]. 
Dijelaskan dalam penelitian bahwa e-modul yang berisikan materi yang jelas menjadikannya sebagai media pembelajaran yang menarik untuk dipelajari. Berbeda dengan modul cetak, e-modul lebih efisien penggunaannya. Karena didalam emodul, berisi materi pelajran dalam bentuk tulisan dan rekman suara bahkan dalam bentuk video. Pada penelitian tentang e-modul mata pelajaran pemrograman web dinamis kelas XI dengan model project based learning di SMK Negeri 2 Tabanan, dalam hal kesesuaian tampilan, kemudahan penggunaan e-modul, motivasi terhadap siswa dan isi konten didapat respon siswa sebesar 91,65\%. Setelah dikonversikan didapat tingkat pencapaian termasuk dalam kategori baik. Sehingga penggunaan e-modul menjadi solusi yang baik terhadap hasil belajar siswa [1][2][3].

Dalam menggunakan e-modul sebagai media pembelajaran ada beberapa kendala yang harus diwaspadai agar dapat ditanggulangi. Beberapa kendala yang sering ditemui dalam penggunaan emodul adalah gangguan internet pada komputer, tampilan dari e-modul yang rumit sehingga sulit bagi siswa memahami fitur yang tersedia dan kurangnya fokus siswa terhadap pembelajaran dikarenakan adanya jaringan internet yang membuat siswa meakses situs lainnya. Untuk menanggulangi masalah sambungan internet maka dapat dilakukan dengan memastikan kabel LAN jaringan tersambung dengan baik. Lalu untuk masalah tampilan e-modul, dapat diperbaiki dengan membuat tampilan user yang simpel dan mudah digunakan dengan menu utama yang jelas. Dalam pembelajaran agar siswa fokus pada pelajaran dapat dilakukan pengawasan oleh guru dan dengan memberikan latihan setelah pelajaran selesai.

Jadi untuk penggunaan e-modul ini sendiri sudah cukup baik respon dari siswa dan dapat lebih dikembangkan lagi agar dapat digunakan sebagai media pembelajaran yang interaktif antara peserta didik dan pendidik sendiri. Dengan perbaikan dan pengendalian dari permasalahan yang muncul serta disempurnakan dengan fitur yang telah ditingkatkan e-modul bahkan dapat didistribusikan ke instansi pendidikan sebagai media interaktif yang efektif dan dapat digunakan dalam proses pembelajaran.

\section{Kesimpulan}

Sebagai media pembelajaran e-modul sudah cukup baik dan layak digunakan. Penggunaan emodul lebih menarik bagi peserta didik daripada media modul cetak biasanya. Dalam beberapa penelitian sudah dijelaskan efektifnya modul sebagai media pembelajaran. Maka dari itu e-modul dapat digunakan sebagai media pembelajaran dan akan lebih menarik dengan inovasi lainnya. Project Based Learning (PjBL) merupakan sistem pembelajaran dengan sistem yang memberikan kesempatan dan ruang kepada peserta didik untuk mengolah dan mengelola pembelajaran di ruang kelas dengan melibatkan banyak orang atau kerja proyek.

\section{Daftar Rujukan}

[1] Suantara K.D, Gede D.W, dkk. (2019). Pengembangan E-Modul Berbasis Model Pembelajaran Project Based Learning Pada Mata Pelajaran Pemrograman Grafik Kelas XII Rekayasa Perangkat Lunak Di SMK Negeri 2 Tabanan. Kumpulan Artikel Mahasiswa Pendidikan Teknik Informatika. Vol 8, No 2.

[2] Putra P.P, Made A. W, dan gede P. S. (2017). Pengembangan E-Modul Berbasis Project Based learning pada Mata Pelajaran Administrasi Basis Data Kelas XII Rekayasa Perangkat Lunak di SMK Negeri 2 Tabanan. Kumpulan Jurnal Pendidikan Teknologi dan Kejuruan. Vol 14, No 1.

[3] Pebriyawan D. M, I Gede M D, dkk. (2017). Pengembangan E-Modul pada Mata Pelajaran Pemrograman Web Dinamis Kelas XI dengan Model Project based learning di SMK Negeri 2 Tabanan. Kumpulan Jurnal Pendidikan Teknologi dan Kejuruan. Vol 14, No 1.

[4] Delianti P. I, Nizwardi J. (2020). Efektivitas EModul Berbasis Project Based Learning pada Mata Kuliah Pemrograman Visual. Pendidikan Teknologi dan Kejuruan. Vol 3, No 2.

[5] Luh Putu D. U, Ketut A, I Made A. P. (2019). Efektivitas Model Pembelajaran Tuntas dalam E-Modul Berbasis Project Based Learning. Pendidikan Teknik Informatika. Vol 8. No 1.

[6] Silitongga F. S, Futruah K. (2018). Desain EModul Berbasis Kemaritiman pada Mata Kuliah Kimia Lingkungan dengan Pendekatan Project Based Learning. Pendidikan Kimia. Vol 6. No 2.

[7] Kemendikbud. (2015). Penguatan Pemahaman Kurikulum 2013 Sekolah Menengah Kejuruan. Handout Pendamping Implementasi Kurikulum 2013 SMK Tahun 2015.

[8] Arsyad, Azhar. 2011. Media Pembelajaran. Jakarta: PT. Raja Grafindo Persada.

[9] Asyhar, Rayandra. 2012. Kreatif Mengembangkan Media Pembelajaran. Jakarta: Referensi Jakarta. 